\title{
DAMPAK PENGGUNAAN GADGET TERHADAP PERKEMBANGAN SOSIO-EMOSIONAL ANAK DI RA DWP 1 KANWIL DEPAG PROVINSI SULAWESI TENGAH
}

\author{
Nurul Hasanah ${ }^{1)}$ Moh. Arfan Hakim ${ }^{2)}$ Khaeruddin Yusuf ${ }^{3)}$ \\ ${ }^{1}$ Mahasiswa Program Studi PIAUD FTIK Institut Agama Islam Negeri Palu \\ ${ }^{2}$ Dosen Fakultas Tarbiyah dan Ilmu Keguruan Institut Agama Islam Negeri Palu \\ ${ }^{3}$ Dosen Fakultas Tarbiyah dan Ilmu Keguruan Institut Agama Islam Negeri Palu
}

\begin{abstract}
ABSTRAK
Penelitian ini bertujuan untuk mendeskripsikan dampak penggunaan gadget terhadap perkembangan sosio-emosional anak serta solusi untuk anak yang sudah ketergantungan oleh gadget agar perkembangan sosio-emosionalnya tidak terganggu di RA DWP 1 Kanwil Depag Provinsi Sulawesi Tengah. Penelitian ini menggunakan metode kualitatif yang bersifat deskriptif. Teknik pengumpulan data dilakukan dengan menggunakan teknik observasi, wawancara, dan dokumentasi. Sedangkan analisisnya menggunakan tiga alur kegiatan yakni reduksi data, penyajian data dan verifikasi data menggunakan triangulasi sumber dan triangulasi metode. Hasil penelitian menunjukkan bahwa ada beberapa anak yang sosio emosionalnya terganggu namun kognitifnya berkembangan karena adanya gadget. dan ada juga beberapa anak yang mahir bahasa inggris melalui gadget tanpa orang tuanya ajari, mereka hanya melihat dan mendegar dari gadgetnya, ada juga yang sudah pintar menulis dan mengenali huruf dari gadget melalui pembiasaan orang tua namun melalui gadget juga. Terlepas dari itu ada juga yang terkena dampak negatifnya seperti susah tidur, tidak terkontrolnya emosi atau agresif, mudah marah, terpapar radiasi dan sensitif. Adapun solusi untuk anak yang sudah ketergantungan oleh gadget yaitu: pilih sesuai dengan usianya, selektif dalam memilih aplikasi permainan dalam gadget, temani anak dalam bermain gadget, batasi anak untuk bermain gadget,mengajak anak melakukan kengiatan positif. Berdasarkan hasil penelitian dapat di simpulkan bahwa kurangnya pengawasan dan ketegasan dan contoh dari orang tualah yang membuat anak menjadi kecanduan gadget, batasi durasi waktu pemakaiannya dan bahan tontonanya perlu di perhatikan.
\end{abstract}

Kata Kunci : Gadget, Sosio-emosional

\section{PENDAHULUAN}

Indonesia sebagai populasi penduduk terbanyak keempat di dunia dan juga termasuk sebagai salah satu negara pengguna gadget terbesar. Disebuah perusahaan media, data, dan riset online di bidang ekonomi dan bisnis yang didirikan pada tanggal 1 April 2012 di Jakarta, mereka juga dipercaya karena telah terdaftar di 
KOMINFO bahwa smartpone yang telah digunakana oleh masyarakat Indonesia dari tahun 2016 ada 65, 2 juta unit smartphone, pada tahun 2017 meningkat menjadi 74,9 juta unit smartphone, tahun 2018 meningkat lagi menjadi 83,5 juta unit smartphone sampai pada tahun 2019 telah menjadi 92 juta unit smartphone ${ }^{1 .}$.

Berdasarkan apa yang telah kita lihat dilingkungan kita pengguna gadget bukanhanya orang dewasa namun juga anak remaja bahkan anak usia dini telah mahir menggunanakannya. Hal ini tidak dapat dipungkiri karena adanya perkembangann zaman, semuanya menjadi mudah dan praktis dengan adanya gadget. Gadget adalah sebuah alat elektronik yang sangat dibutuhkan dizaman sekarang ini sebagai salah satu alat untuk mempermudah pekerjaan manusia. Gadget adalah perangkat elektronik kecil yang memiliki fungsi khusus. Diantaranya smartphone seperti iphone dan blackberry, serta notebook(perpaduan antara komputer portable seperti note book dan internet).

Saat ini banyak negara sedang mengalami musibah termasuk salah satunya Indonesia yang disebut dengan pandemi covid-19 atau corona, pandemi ini mempengaruhi banyak hal termasuk salah satunya aktifitas di luarrumah. Untuk mencegah peyebaran virus corona pemerintah menganjurkan masyarakat untuk berdiam diri di rumah saja dengan melakukan work from home saja dan menghindari keramaian. maka dari itu mulai dari orang yang bekerja di kantor, di tempat perbelanjaan, bahkan sekolah di liburkan dan di anjurkan untuk di rumah saja, agar semuanya tetap berjalan seperti biasanya walaupun tidak sepenuhnya, kebanyakan orang melakukan aktivitasnya dirumah saja melalui gadget. Mulai dari aktivitas kantoran, perbisnisan, bahkan para siswa mulai dari tk sampai perguruan tinggi dianjurkan tetap belajar namun secara online melalui gadget yang disebut dengan belajar daring.

Belajar daring adalah belajar jarak jauh secara online tanpa melakukan tatap muka langsung namun tatap muka melalui platfrom yang telah tersedia ${ }^{2}$. Dengan kondisi seperti ini secara tidak langsung anak akan selalu hidup berdampingan dengan gadget, dan lebih banyak menghabiskan waktu dengan gadget, karena banyak fitur-fitur yang menarik di dalamnya yang bisa menjadi penarik perhatian bagi mereka, contohnya game, film atau video-video pendek yang memakai ilustrasi yang lucu, dengan seperti ituresiko anak terkena dampak gadget akan lebih

1 Oik yusuf, pengguna internet Indonesia nomor enam dunia, https://kominfo.go.id, sorotan_mediahasil web Indonesia RaksasaTeknologi Digital Asia-kementrianKomunikasi dan Informatika. (diakses 18 agustus 2019).

2 Ardita Syalwa, pembelajaran daring, efektif?, https://www.kompasiana.com/arditasyalwa/5e 7ba8d6097f36116506b8a2/pembelajaran-daringefektif. (Diakses 14 juni 2020). 
besar. Penggunanaan gadget yang berlebihan akan memberikan dampak buruk bagi sosio-emosional anak karena anak akan menjadi seorang yang pendiam, penyendiri, pemarah serta malas untuk melakukan aktifitas lainnya. Mereka hanya asyik dengan dunia mereka sendiri karena di dalam gadgettersebut banyak aplikasi-aplikasi yang menyenangkan mereka seperti game, dan aplikasi tontonan seperti youtube yang sangat menarik bagi mereka karena bahan tontonan di dalam bukan hanya ada satu tapi ada jutaan bahan tontonan didalamnya dengan berbagai situs. Nah jika anak tidak diawasi dalam menggunakan gadget bisa saja bahan tontonanya nanti sudah tidak senonoh atau tidak sesuai dengan umurnya. Karena anak yang pada usia dini sebagai peniru yang ulung maka mereka bisa saja menirukan langsung apa yang mereka nonton tadinya, jika bahan tontonanya tidak baik maka apa yang mereka lakukan akan tidak baik juga.

Gadget tidak hanya memiliki kekurangan tapi juga memeliki kelebihan yang dapat memberikan pengetahuan bagi anak sesuai bahan tontonannya.Salah satunya pengenalan angka dan huruf. Anak usia dini yaitu anak yang berada dalam masa pertumbuhan dan perkembangan. Untuk itu sangat penting untuk memperhatikan gerak gerik, tingkah laku serta emosinya agar pertumbuhan dan perkembanganya sesuai dengan umurnya. Bukan hanya memperhatikan masa pertumbuhan mereka, namun juga pada masa sekolah danmasa pra sekolah karena akan berpengaruh besar pada pertumbuhan serta perkembangannya nanti.

Pada perkembangan sosio-emosional anak, lingkungan sekitar sangatlah berpengaruh baik dari orang tua, guru, serta masayarakat. Karena mereka dapat mengontrol serta membantu bahkan bisa juga menjadi pemicu anak untuk bermain gadget. Karena itu perlu kiranya untuk mengetahuitentang sosio dan emisonal anak untuk menjadi pedoman dalam mendidik dalam perkembangan sosio-emosional anak serta dampak gadget pada perkembangan sosio-emisonal anak. Karena berdasarkan hasil observasi, banyak anak yang sekolah di RA DWP 1 Kanwil Depag Provinsi Sulawesi Tengah telah menggunaka gadget dan banyak juga di antara mereka telah terkena dampak dari penggunaan gadget, baik dari dampak negatif maupun positif dari gadget.

Maka berdasarkan uraian di atas maka penulis tertarik untuk mengadakan penelitian mengenai gadget dan sosio-emosional anak yang berjudul "Dampak Penggunaan Gadget terhadap Perkembangan Sosio- Emosional Anak di RA DWP 1 Kanwil Depag Provinsi Sulawesi Tengah"

\section{METODE PENELITIAN}

Peneliti memilih untuk menggunakan penelitian kualitatif, karena penelitian kualitatif sebagai penelitian yang hasilnya tidak diperoleh melalui prosedur statistik atau metode kuantifikasi, melainkan penelitian ini lebih bersifat observasi lapangan. Penulis menggunakan pendekatan naturalistik untuk memahami keadaan yang ada 
dilapangan. Penelitian kualitatif ini merupakan penelitian yang menekankan pada pemahaman mengenai masalah-masalah dalam kehidupan sosial berdasarkan kondisi realitas atau natural setting yang hoilistis, kompleks, dan rinci ${ }^{3}$. Lokasi penelitian yang dipilih oleh penulis yaitu diRA DWP 1 Kanwil Depag Jalan. Bantilan No, 8 Palu Provinsi Sulawesi Tengah, sebagai tempat untukmengamati anak usia dini yang dijadikan sebagai objek penelitian, dikarenakan disekolah tersebut banyak anak yang sudah mahir menggunakan gadget yang bisa menyebabkan mereka mengalami gangguan sosio dan emisonal selain itu juga untuk mendapatkan informasi yang lebih detail dan akurat untuk masalah yang dikaji.

Teknik pengumpulan data yang digunakan meliputi teknik observasi, wawancara dan dokumentasi. Adapun teknik analisis data terdiri dari proses reduksi data, penyajian data dan verifikasi data. Pengecekan keabsahan data dalam penelitian ini melalui diskusi dengan berbagai kalangan yang memahami masalah penelitian ini yaitu dengan sumber-sumber yang sudah memahami dan berpengalaman mengenai meningkatkan kosakata pada anak melalui metode bermain peran. Pengecekan keabsahan data dilakukan untuk mengetahui apakah data-datapeneliti benar-benar valid. Adapaun data yang dapat dipercaya jika tidak ada perbedaan antara yang dilaporkan peneliti dan apa yang ada dilapangan atau objekyang diteliti. Untuk mngetahui hal tersebut peneliti melakukan validitas data atau pengecekan keabsahan data.

\section{HASIL DAN PEMBAHASAN}

A. Dampak penggunaan gadget terhadap terhadap perkembangan sosioemosional anak di RA DWP 1 Kanwil Depag Provinsi Sulawesi Tengah

Di era sekarang ini gadget semakin merajalela, dari bentukknya yang semakin tipis dan aplikasi didalamnya yang semakin beragam sehingga menjadi daya tarik yang kuat untuk orang orang dewasa bahkan anak usia dini untuk memilikinya, bukan hanya orag tua namun juga bagi anak usia dini memiliki serta menggunanakan gadget sangat banyak dampak yang akan ditimbulkan, mengigat anak usia dini masih dalam fase pertumbuhan dan perkembangan yang dapat menjadi penentu dikemudian hari. dampak yang dapat ditimbulkan dari penggunaan gadget bukan hanya positif namun juga negatif. Dampak positif gadget sebagai berikut:

\section{Berkembangnya imajinasi}

Anak usia dini anak yang sedang tumbuh dan berkembang. Pada usia ini

${ }^{3}$ Anggito Albi, Metode Penelitian Kualitatif, (Cet. I; Jakarta: CV Jejak, 2018), 9 
imajinasi anak sangat berkembang sesuai berjalannya waktu. Orang tua sangat berperan untuk menstimilus agar imajinasinya berkembang dengan baik. Imajinasi anak timbul dari apa yang ia lihat dan amati. contohnya saat ia bermain karena dunia anak tidak bisa lepas dari dunia bermain. Saat ini banyak anak yang hanya memilih bermain gadget daripada bermain dengan temannya apalagi melihat kondisi sekarang ini. Namun disamping itu imajinasi anak tetap berkembang. Apa yang dia lihat digadget dan dia amati setiap harinya dapat ia tuangkan dalam bentuk gambar maupun tulisan. Hal tersebut sesuai dengan hasil observasi penulis sebagai berikut: Aipe ketika diperintahkan untuk mewarnai sebuah sketsa kupu-kupu. Aipe mengambil pensil warna yang berwarna ungu meskipun kupu-kupu yang ia lihat digadgetnya bewarna orange.

Berdasarkan hasil observasi diatas, dapat difahami bahwa imajinasi anak sudah mampu berkembang baik berdasarkan dengan apa yang dia lihat dan amati selama ini melalui gadgetnya dan lingkungan sekitarnya. Hal tersebut sesuai ungkapan dari ibu ulmi sebagai berikut:

"anak saya itu sering memang bermian gadget, setelah itu dia biasanya minta buku untuk diwarnai sama pensil warnanya kemudian ia menggambar apa yang dia lihat tadi, namun saya perhatikan kalau dia menggambar kadang warna atau bentuk yang dia gambar tidak sesuai dengan apa yang sudah dia lihat tapi sesuai dengan keinginannya saja, contohnya itu kupu-kupu tadi, yang biasa dia lihat warna biru tapi karena warna kesukaannya warna ungu jadi dia warnai kupu-kupunya menjadi warna ungu" 4

Berdasarkan penjelasan diatas bahwa anak mewarnai gambarnya bukansesuai apa yang dia lihat namun sesuai dengan keinginannya sehingga dapatdisimpulkan bahwa imajinasi anak sudah berkembang.

\section{Melatih kecerdasan}

Ada berbagai macam cara untuk melatih kecerdasan anak salah satunya dengan cara pembiasaan, tergantung dari orang tuanya. Apalagi zaman sekarang ini, kebayakan anak lebih suka bermain gadget daripada bermain bersama temannya, terlebih situasi sekarang ini masa covid, tentunya orang tua lebih takut membiarkan anaknya untuk bermian di luar. Ketika bermain gadget. Contohnya didalam rumah, orang tuanya membelikan poster huruf-huruf dan menempelnya didinding maka dengan itu anak akan sering melihat dibantu orang tua sering mengajak untuk menyebutkan huruf tersebut, maka anak akan terbiasa hingga ia tau huruf itu, sama seperti anak yang bermain gadget dan sering menonton youtube yang konten

${ }^{4}$ Ulmi ibu dari Zahnas Go Guang Yi dan nurul Az-Zahira Rabbiana, "wawancara diterasrumah. Tanggal 16 juli 2020. 
dalamnya tentang pembelajaran seperti mengenal angka, huruf warna dan masih banyak lagi. Penjelasan diatas sesuai dengan ungkapan ibudari Dinanti rahma putri sebagai berikut:

"anak saya bisa bahasa inggris karena bermain gadget, kalau ditanya- tanya dia tahu untuk menjawab karena yang biasa dia tonton di youtube kontenkonten bahasa inggris untuk anak. Contohnya mengenal warna, angka, huruf dalam bahasa inggris". 5

Berdasarkan ungkapan dari ibu musni diatas dapat disimpulkan bahwa anak akan pelan-pelan akan tahu sesuatu jika dibiasakan. Semuanya tidak terlepas dari peran orang tua yang sangat penting dalam membantu perkembangan serta pertumbuhan anak sebagai penentu kedepanya. Oleh karena itu, sebagai manusia mulailah membiasakan anak sejak dini hal-halyang positif agar nanti kedepannya orang tua tidak susah lagi untuk mengatur anaknya.

\section{Meningkatkan rasa percaya diri.}

Rasa percaya diri bukanlah kemampuan yang datang dengan sendirinya melainkan harus dengan cara dilatih, apalagi untuk menumbuhkan dan meningkatkan rasa kepercayaan diri anak usia dini. Namun banyak cara yang dapat dilakukan orang tua untuk membangun meningkatkan rasa kepercayaan diri seorang anak. Contohnya ketika anak mengikuti lomba mewarnai dan mendapatkan juara pertama. Lalu dia mendapatkan pujian dan tepuk tangan, semua itu dapat meningkatkan rasa kepercayaan dirinya. Sama dengan ketika anakbermain game, dia memainkan game lalu menang itu dapat juga dapatmembangkitkan kepercayaan dirinya untuk bermain lagi bahkan menunjukkan ke teman-temannya.

Berdasarkan hasil observasi yang penulis lakukan, bahwa raffa ketika bermain game di percobaan pertama dia menang lalu bermain lagi kemudian kalahnamun dia tetap mencoba untuk bermain lagi dipercobaan ketiga bahkan percobaan selanjutnya, ia tidak patah semangat untuk mengulang gamenya sampaiia menang lagi beda halnya dengan raffi, ketika dia bermian game di percobaan pertama dia menang namun dipercobaan kedua dia kalah, maka dia langsung berhenti memainkan game tersebut bahkan mencari game lainnya dimana dia bisa menang terus dan menganggap dirinya hebat.

Berdasarkan hasil observasi di atas dapat dipahami bahwa rasa kepercayaan diri anak tidak hanya dapat dibangun dengan pujian langsung dari orang tuanya atau guru bahkan orang-orang disekitarnya namun rasa kepercayaan diri seorang anak dapat dibangun juga melalui kemenangan yang dia dapatkan ketika bermain game.

5 Musni, ibu dari Dinanti Rahma Putri, "wawancara”. Diruang belajar B2 RA DWP 1 Kanwil Depag, tanggal 14 juli 2020 


\section{Mengembangkan kemampuan dalam membaca, matematika, dan pemecahan masalah.}

Zaman sekarang ini anak sudah tidak bisa diajarkan membaca atau matematika dengan teknik lama, yaitu harus duduk di depan bukunya. Namun orang tua bisa memanfaatkan gadget sebagai saran untuk anak belajar, karena anak sekarang lebih tertarik bermain gadget daripada harus berhadapan dengan buku. Orang tua bisa memanfaatkan youtube dengan atau televisi dengan chanel anakanak. Karena tanpa disadari anak-anak bisa belajar dari hasil eksplorasinya yang dia lihat tanpa ada pemaksaan dari orang tua. Sebangian anak bisa belajar membaca dan mengenal huruf dari gadget. Seperti yang telah disampaikan ibu musni kepada penulis sebagai berikut:

"dinan bermain hp biasanya nonton youtube dan chatingan lewat aplikasi whatsaap sama bapaknya karena bapaknya jauh ada dijawa, sudah satu tahun tidakketemu makanya saya biarkan dia bermain hp. Tapi tetap dalm pengawasan saya walaupun tidak selalu didekatnya kalua dia bermain hp, paling saya pantau sebentar sebentar saja. Saya juga melarang bapaknya dinan kalau chatigan sama anaknya untuk menggunakan voice note agar dinan bisa belajar menulis danmembaca dari situ" 6

Sebagaimana yang dikatakan oleh ibu musni diatas, maka dapat disimpulkan bahwa dinan bisa belajar membaca dan menulis karena orang tuanya pintar melihat perkembangan zaman serta memanfaatkan tekhnologi canggih sebagai sarana dan prasarana untuk belajar anak tanpa adanya pemaksaan dari orang tua lagi karena anak bisa belajar dari hasil eksplorasinya sendiri tanpa orang tua sadari.

Setelah dampak positif gadget ada juga beberapa dampak negatif yang ditimbulkan akibat menggunakan gadget sebagai berikut:

\section{Menjadi pribadi yang tertutup}

Dalam menggunakan gadget sebagai alat komunikasi lebih merasanyaman dibanding berkumpul sambil ngobrol dengan temannya dan yang terakhir menjadikannnya kaum berdzikir karena selalu menunduk ke bawah melihat gadgetnya tanpa melakukan interaksi sosial kepada orang lain di sekitarnya. Anak lebih nayaman dengan kesendiriannya namun dia tidak merasa sendiri karena anak merasa gadgetnya lebih mengasyikkan daripada harus bermain di luar bersama temannya ditambah melihat kondisi sekarang ini masih masa pandemi, kebayakan orang tua tidak memberikan izin anaknya untuk bermian di luar karena takut tertular

\footnotetext{
6 Musni, ibu dari Dinanti Rahma Putri, "wawancara”. Diruang belajar B2 RA DWP 1 Kanwil
} Depag, tanggal 14 juli 2020 
virus corona jika dia berkumpul bersama temannya. Ada juga orang tua yang memang takut anaknya untuk bermain diluarkarena takut anaknya akan disakiti oleh temannya dan lebih membelikan permainan dirumah atau melengkapi fasilitas bermain anaknya dirumah agar anaknya tidak minta bermain diluar, contohnya dengan membelikan anak handphone atau tablet $P c$, boneka, atau permainan anak apa saja yang dia inginkan agar supaya tidak bermain diluar. seperti yang diungkapkan ibu fadlia sebagai berikut:

"raffa saya tidak beri izin bermain di luar, apalagi sekarang masih kondisi covid jadi saya takut, saya juga kasian sama raffa, kalau dia bermain diluar kadang pulang sudah menangis, takut juga saya apa biasa temannya kalau bermain sering di pinggir jalan atau biasa memanjat pagar-pagar besi yangujungnya tajam-tajam itu, jadi raffa saya suruh bermain dirumah saja samakakaknya, karena dia juga kalau lowbet hp pindah ke tv, kalau bosan pindah ke hp, jadi sudah malas juga bermain di luar"7

Melalui ungkapan di atas dapat dipahami bahwa anak menjadi pribadi yang jarang bersosialisasi pertama, karena keadaan sekarang ini masih pandemicsehingga orang tuanya takut anaknya bermain diluar, kedua, karena orang tuanya sudah memberikan fasilitas dirumah sehingga menjadikannya nyaman untuk dirumah saja daripada bermain dengan temannya diluar.

\section{Gangguan tidur}

Anak yang selalu bermain gadget akan membuat dia mengalami gangguan tidur karena mereka terpapar cahaya layar yang menyala dari gadget mereka dari dekat. Paparan cahaya dari gadget itu yang menurunkan kadar hormon melatonin dalam tubuh. Melatonin merupakan zat alami dari tubuh yang membantu manusia untuk tidur dengan cara memberitahukan kepada tubuh bahwa keadaan disekitarnya sudah gelap, saatnya untuk tidur. Sehingga jangan heran jika anak anda memengang handphone dengan posisi tangan dengan mata yang sangat dekat sebelum tidur sampai tengah malam ia belum merasakan mengantuk, itu semua karena anak terkena paparan cahaya layar yang memberitahukan kepada tubuh bahwa hari masih terang belum saatnya untuk tidur. Sebagaimana yang dijelaskan ibu sri adi ningsih sebagai berikut:

"lalu raffi sering sekali tidur tengah malam karena main hp terus, kalau disuruh tidur katannya belum mengantuk ibu, sampai biasanya saya heran saya saja sudah mengantuk kenapa dia tidak mengantuk padahal sudah jam 11 malam, nanti saya sudah marah, saya ambil hp dari

${ }^{7}$ Fadlia ibu Raffa al-Gazali, "wawancara”, di Ruang belajar B2 RA DWP 1 Kanwil Depag. Tanggal 14 juli 2020 
tanganya baru dia tidur. Itu lalu waktu hp masih saya simpan sembarang sekarang hp sudah saya sembunyi, jadi dia sudah tidur tepat waktu" 8 .

Ibu ulmi juga mengungkapkan hal yang sama sebagai beikut:

“Anak saya juga kalau sudah main hp, tidak tidur sampai jam 12, itupun nanti dipaksa-paksa tidur kalau tidak begitu tidak tau mau sampe kapan barumau tidur. ini saja sampe sakit karena bagadang terus, ini batuk-batu sudah, tidak lama lagi demam ini, baru kakak ade itu sama-sama suka main gadget itu, tidak tau berhenti" ${ }^{9}$.

Berdasarkan ungkapkan di atas dapat disimpulkan bahwa anak jika sudah bermain gadget maka mereka akan mengalami gangguan tidur atau susah untuk tidur maka perlu pengawasan dari orang tua, ketika anak sudah waktunya tidur peringatkan untuk tidak memengang gadget lagi agar supaya tidurnya tidak larut malam lagi dikarenakan terlalu asyik bermain gadget.

\section{Anak lebih mudah mengalami masalah mental (emosional) seperti anak} lebih agresif, mudah marah, sensitive, dan mudah tersinggung.

Ketika anak sudah kecanduan bermain gadget anak bisa menjadiemosional karena anak sudah kehilangan kontrol diri sehingga menyebabkan kecemasan dan depresi. Anak yang usah kecanduan gadget akan merasa cemas jika dia dipisahkan dengan gadgetnya. Contohnya raffa ketika ia tidak diberikan hp, maka dia akan mengamuk sampai memukul kedua orang tua. Hal tersebut sesuai dengan ungkapan ibu fadlia sebagai beikut:

"saya kasi hp sama raffa supaya dia tidak mengamuk, karena kalau dia tidak dikasi hp,dia pasti mengamuk sampe bapukul-pukul itu, papanya saja dia pukul apalagi cuma saya, dia main game dihp, kalau bukan dia menonton youtube ditv, jadi kalau lowbet hpnya dia pindah ke tv, begitu terus" 10 .

Dari ungkapan ibu fadlia diatas dapat dipahami bahwa raffa sudah mulai kehilangan kontrol emosi serta depresi jika dipisahkan dari gadgetnya. Hal itu dapat dilihat ketika raffa sampai berani memukul ibu bahkan ayahnya sekaligus jika ia tidak diberikan gadgetnya.

\footnotetext{
${ }^{8}$ Sri Adi Ningsih ibu dari Raffi, "wawancara” diruang belajar B2 di RA DWP 1 KanwilDepag. Tanggal 15 juli 2020

9 ulmi ibu dari Zahnas Go Guang Yi dan nurul Az-Zahira Rabbiana, "wawancara diterasrumah. Tanggal 16 juli 2020

${ }^{10}$ Fadlia ibu Raffa al-Gazali, "wawancara”, diRuang belajar B2 RA DWP 1 Kanwil Depag. Tanggal 14 juli 2020
} 
Ibu ulmi juga mengungkapkan hal yang sama sebagai berikut:

"anak sama ai ini kalau saya minta hp mereka pasti mengamuk, marahmarah sama saya itu, biasa lari sembunyi, kalau sudah sembunyi main hp sudah disitu sama kakaknya. Pokoknya tidak bisa sekali diminta hp kalau sementara mereka pake, kalau tidak lowbet tidak mau berhenti, karena saya marah kalau main hp sambil dicas" ${ }^{11}$.

Dari ungkapan ibu ulmi diatas dapat dipahami bahwa anaknya sudah mengalami gangguang mental yaitu mudah marah dan sensitive sehingga ketika mereka dilarang maka akan marah kembali kepada siapa pun yang meminta gadget mereka.

Berdasarkan dua ungkapan diatas dapat disimpulkan bahwa dampak negatif gadget akibat penggunaan jangka panjang dapat mengakibatkan gangguan mental seperti depresi, agresif, mudah marah dan sensitif.

\section{Terpapar radiasi}

Salah satu dampak negatif gadgetnya yaitu terpapar radiasi gadget. Radiasi gelombang elektromagnetik dari gadget memang tidak terlihat, efeknya pun tidak terasa secara langsung mengganggu kesehatan namun efek gadget secara tidak langsung akan dapat mengaganggu kesehatan manusia karena efek radiasi dari teknologi sangat berbahaya bagi kesehatan manusia terutama pada anak-anak. Semakin lama waktu pemakaian gadget semakin besar resiko anak terpapar radiasi $\mathrm{hp}$. Hal tersebut sesuai dengan ungkapan ibu purna sebagai guru kelas b3 sebagai berikut:

"ada pernah kejadian, orang tua minta izin kepada saya, mau bawa anaknya kedokter, katanya mata anaknya merah sekali, karena suka sekali main hp tidak kenal waktu pokoknya, akhirnya karena pengaruh radiasi mata anaknya merah dan sakit, sampai dikasi obat sama dokter dan tidak sekolah selama 2 hari" ${ }^{12}$

Berdasarkan ungkapan diatas dapat disimpulkan bahwa radiasi dari layar gadget sangat berbahaya apalagi untuk penglihatan atau mata, bahkan sangat berpengaruh. Memang belum semua orang yang bermain gadget langsung terkena radiasi sampai sakit karena dampaknya tidak bisa langsung dirasakan tapi jika

11 ulmi ibu dari Zahnas Go Guang Yi dan nurul Az-Zahira Rabbiana, "wawancara diterasrumah. Tanggal 16 juli 2020

12 Purnaningsih guru kelas b3, "wawancara”, diruangan kepala sekolah RA DWP 1 KanwilDepag Provinsi Sulawesi Tengah. Tanggal 15 juli 2020 
bermian gadget berkelanjutan akan berdampak sangat bahaya seperti yang dikatakan ibu purna diatas. Jika tidak ingin terpapar radiasi dari layar gadget, batasi waktu penggunaan gadget bagi anak, perhatikan durasi pemakaiannya serta kurangi kecerahan layar jika digunakan ditempat terang dan jangan menggunakan gadget didalam keadaan ruangan yang gelap

\section{B. Solusi untuk anak yang sudah ketergantungan dalam menggunakan gadgetagar sosio-emosionalnya tidak terganggu}

Kunci utama solusi untuk anak yang sudah ketergantungan dengan gadget adalah orang tuanya. Sikap orang tualah yang dapat mengontrol semuanya. Diantara sikap yang dapat dilakukan orang tua sebagai berikut:

\section{Pilih sesuai dengan usia anak}

Orang tua boleh-boleh saja memberikan gadget kepada anak-anak usia dini namun harus disesuaikan dengan usianya. Untuk usia dibawah 5 tahun orang tua bisa mengenalkan anak perangkat yang bermanfaat contohnya mengenalkan warna, bentuk, mengajarkan untuk berhitung sederhana serta menambahkan kosa kata. Untuk usia 5 tahun keatas orang tua bisa memilihkan aplikasi yang bisa didownload oleh anak. Usahakan aplikasi yang didownload oleh anak aplikasi yang tidak bersifat kekerasan atau adanya paparan seksual. Untuk bahan tontonannya orang tua bisa menggunakan youtube kids, didalam youtube kids isi kontennya semua tentang anak-anak. hal tersebut berbedadengan ungkapan ibu ulmi sebagai berikut:

"saya tidak memilih atau membatasi tontonan mereka namun alhamdulillah anak-anak saya juga tidak tertarik dengan hal yang mengandung konten dewasa, mereka hanya tertarik menonton kontenkonten slime, atau kartun-kartun lainnya di youtube yang disambung dengantelevise, namun biasa ada iklan-iklan yang tidak baik muncul hanya itu saja" 13 .

Berdasarkan apa yang diungkapkan ibu ulmi diatas dapat disimpulkan bahwa orang tua tidak membatasi bahan tontonan anak-anaknya sesuai usainya namun anaknya sendiri yang bisa selektif dalam memilih bahan tontonannya.

\section{Selektif dalam memilih aplikasi permainan dalam gadget}

Orang tua harus selektif dalam memilih aplikasi digadget. Apalagi aplikasi untuk tontonan dan permainan. Untuk saat ini youtube telahmenyediakan youtube untuk anak yang isinya hanya konten untuk anak-anak tanpa adanya konten dewasa yang tidak bisa atau tidak wajar untuk dinonton oleh anak-anak. Orang tua juga bisa memilihkan aplikasi permainan yangbermanfaat, contohnya jenis game puzzle yang

13 ulmi ibu dari Zahnas Go Guang Yi dan nurul Az-Zahira Rabbiana, "wawancara diterasrumah. Tanggal 16 juli 2020 
mencocokkan warna, bentuk dan masih banyak yang lain lagi. Sebagaimana ungkapan ibu ulmi sebagai berikut:

"karena anak saya suka menggambar dan mewarnai, jadi mereka menginstal aplikasi untuk mewarnai, saya juga tidak larang itu karena aplikasinya juga bagus, malah anak-anak makin senang" ${ }^{14}$.

Berdasarkan ungkapan di atas dapat dipahami bahwa banyak aplikasi yang bermanfaat yang ada digadget yang dapat diinstal dan menambah wawasan serta menyenangkan bagi anak, bukan hanya game yang hanya menghabiskan tenaga anak atau bahkan game kekerasan yang nantinya tanpa disadari ia akan peraktekkan kepada temannya. Maka dari itu orang tua juga perlu mengawasi dan seletif dalam memilih aplikasi untuk anak-anak.

\section{Temani anak dalam bermain}

Alangkah baiknya orang tua mendampigi anak untuk bermain gadget, agar dapat mengontrol anak juga. Jika orang tua tidak bisa selalu menemani sampai lama usahakan bisa menyisihkan waktu walau hanya 5 menit untuk menemani anak untuk bermain gadget agar supaya anak ketika kesulitan atau melihat hal baru orang tua bisa mengajari, menjelaskan atau membantu anak untuk menyelesaikan masalahnya. Jika anak berhasil menyelesaikan misi dalam permainan berikan apresiasi seperti tepuk tangan agar anak senang dan tanpa disadari anak dapat belajar dari permainan tersebut. orang tua juga bisa mengenalkan anak permainan yang bukan didalam gadget agar supaya diatidak hanya terpaku dengan gadgetnya. Contohnya permainannya mengajak anak bermain conglak. Dalam permainan congklak orang tua bisa mendampigi anak bermain sambil belajar menghitung serta mengajarkan antri. Hal tersebut sesuai dengan apa yang dikatakan ibu musni sebagai berikut:

"kalau dinan main hp saya tidak juga selalu temani sampai duduk berjam- jam disitu selama dia main hp, saya Cuma awasi sebentarsebentar saja, saya tengok apa yang dia nonton, apa yang dia mainkan, namanya juga ibu rumah tangga bukan Cuma satu kerjanya jadi kalau saya awasi anakku main hp yah saya lihat sebentarsebentar saja" 15 .

${ }^{14}$ ulmi ibu dari Zahnas Go Guang Yi dan nurul Az-Zahira Rabbiana, "wawancara diterasrumah. Tanggal 16 juli 2020

${ }^{15}$ Musni, ibu dari Dinanti Rahma Putri, "wawancara”. Diruang belajar B2 RA DWP 1 Kanwil Depag, tanggal 14 juli 2020 
Dari ungkapan di atas dapat dipahami bahwa orang tua harus menyempatkan diri untuk menemani anaknya ketika bermain gadget walaupun hanya sebentar agar orang tua bisa mengontrol apa saja yang dilihat anaknya.

\section{Batasi anak untuk bermain gadget}

Agar anak tidak ketergantungan dengan gadget orang tua harus mengajarkan kedisiplinan kepada anak sejak dini. Salah satunya disiplin waktu.Buatlah perjanjian kepada anak berapa lama anak diperbolehkan menggunakan gadget dalam sehari dan dimana saja anak tidak boleh menggunakan gadget. Untuk anak usia 5 tahun keatas boleh saja menggunakan gadget contohnya dengan batasan waktu sampai setengah jam atau saat hari libur. Orang tua juga harus membatasi anak untuk tidak menggunakan gadget ketika sedang berada diruang makan atau sedang makan agar komunikasi tetap berjalan seperti biasanya, tidak menggunakan gadget sebelum tidur agar tidurnya tepat waktu. Dalam wawancara penulis kepada ibu sri adi ningsih mengatakan hal yang sesuai dengan penjelasan diatas bahwa:

"dulu ketika saya masih menyimpan hp sembarangan, tidak ada batasan waktu untuk raffi bermain gadget, tapi sekarang semenjak saya sudah simpanbaik-baik hp, sudah dibatasi dia juga pengang hp, saya kasi dia penganghp biasa Cuma 1 sampai 2 jam saja tidak lebih" ${ }^{16}$.

Namun berbeda dengan ungkapan ibu ulmi sebagai berikut:

"saya tidak berikan batasan waktu untuk anak saya bermain hp, saya Cuma larang sekali kalau sementara dicas terus hpnya tetap juga dimainkan, jadi kakak ade itu berhenti main gadget kalau sudah lowbet, kalau tidak sampai berapa jam itu hp bertahan sampai itu juga mereka tetap mainkan itu hp" ${ }^{17}$.

Dari dua ungkapan diatas memiliki perbedaan, ungkapan yang pertama bahwa orang tuanya membatasi waktu anaknya untuk bermain gadget namun, orang tua kedua tidak membatasi waktu untuk anaknya bermain gadget sehingga tidak heran, anak dari ibu ulmi mengalami gangguan tidur dan gangguan emosi karena mereka sudah mengalami kecanduan gadget walaupun masih usia dini.

\section{Mengajak anak untuk melakukan kegiatan positif}

Pada masa pandemi ini karena dibatasi untuk keluar rumah banyak melalukan

${ }^{16}$ Sri Adi Ningsih ibu dari Raffi, "wawancara" diruang belajar B2 di RA DWP 1 KanwilDepag. Tanggal 15 juli 2020

17 ulmi ibu dari Zahnas Go Guang Yi dan nurul Az-Zahira Rabbiana, “wawancara diterasrumah. Tanggal 16 juli 2020 
hal baru dirumah. Contohnya seperti mencoba resep baru, menanambunga dan masih banyak hal lainnya. Orang tua bisa mengajak anak untuk melakukannya bersama atau mengajak agar anak tidak hanya bermain gadget sambil mengenalkan kepada anak-anak walaupun mereka mbelum mengerti sepenuhnya. Itu salah satu bentuk pengalihan orang tua, agar anaknya tidak hanya terpaku gadget kemudian orang tua juga bisa membangun komunikasi dan kedekatan lebih ketika mereka mengerjakan sesuatu bersama-sama. Sebagimana yang dikatakan ibu musni sebagai berikut

"saya tidak melarang anak saya melakukan apa saja bahkan jika dia menganggu saya memasak, bahkan saya lebih suka lagi kalau dia ikut saya memasak tanpa saya panggil. Mau dia potong-potong bawang disitu, saya tidak akan marah, karena dinan anak perempuan satusatunya, jadi bapaknya berpesan untuk biasakan ajar dia memasak dari kecil" 18 .

Dari ungkapan diatas dapat disimpulkan bahwa orang tua bisa mengajarkan anak-anak hal-hal yang positif dari kecil sebagai bentukpembiasaan agar ketika besar tida nanti oang tuanya marah baru dia mengerjakan pekerjaannya.

\section{KESIMPULAN}

Berdasarkan hasil penelitian menunjukkan bahwa anak di RA DWP 1 Kanwil Depag Provinsi Sulawesi Tengah telah mengalami dampak dari penggunaan gadget tentu saja dampaknya bukan hanya negatif namun juga ada yang positif. Ada beberapa anak yang sosio emosionalnya terganggu namun kognitifnya berkembangan karena adanya gadget. Dan ada juga beberapa anak yang mahir bahasa inggris melalui gadget tanpa orang tuanya ajari, mereka hanya melihat dan mendegar dari gadgetnya, ada juga yang sudah pintar menulis dan mengenali huruf dari gadget melalui pembiasaan orang tua namun melalui gadget juga. Terlepas dari itu ada juga yang terkena dampak negatifnya seperti susah tidur, tidak terkontrolnya emosi atau agresif, mudah marah, terpapar radiasi dan sensitif.

Adapun solusi untuk anak yang sudah ketergantungan oleh gadgetyaitu: pilih sesuai dengan usianya, selektif dalam memilih aplikasi permainan dalam gadget, temani anak dalam bermain gadget, batasi anak untuk bermain gadget,mengajak anak melakukan kengiatan positif. Berdasarkan hasil penelitian dapat di simpulkan bahwa kurangnya pengawasan dan ketegasan dan contoh dari orang tualah yang

18 Musni, ibu dari Dinanti Rahma Putri, "wawancara”. Diruang belajar B2 RA DWP 1 Kanwil Depag, tanggal 14 juli 2020 
membuat anak menjadi kecanduan gadget, batasi durasi waktu pemakaiannya dan bahan tontonanya perlu di perhatikan

\section{SARAN}

Berdasarkan hasil penelitian yang telah dilakukan penulis di RA DWP 1 Kanwil Depag Provinsi Sulawesih Tengan mengenai dampak penggunaan gadget terhadap perkembangan sosio-emosional anak memiliki beberapa masukan atau saran sebagai berikut bagi orang tua anak seperti berikut:

a. Diharapkan orang tua dapat meluangkan waktunya walau hanya sebentar untuk mengawasi anaknya ketika bermain gadget agar supaya dapat mengontrol anaknya sehingga bijak dalam menggunakan gadget dan orang tua juga bisa membangun komunikasi bersama anaknya.

b. Biasakan disiplin waktu ketika anak menggunakan gadget agar supaya kedepannya anak tidak ketergantungan gadget yanng membuatnya manjadi kaum berdzikir yang selalu menunduk kebawah tanpa memperdulikan sekitarnya atau lingkungannya sehingga membuatnya menjadi pribadi yang tertutup atau kurang tahu bersosialisasi.

c. Orang tua juga wajib memberikan contoh dalam menggunakan gadget,jangan hanya membatasi dan melarang anaknya bermain gadget namun orang tuanyalah yang malah bermain gadget. Berikanlah contoh kepada anak-anak untuk disiplin waktu dan tempat dalam menggunakan gadget.

\section{DAFTAR PUSTAKA}

Anggito Albi dan Setiawan Johan. S.Pd. Metode Penelitian Kualitatif, Cet. I;Jakarta: CV Jejak, 2018.

Ardita Syalwa, pembelajaran daring, efektif https://www.kompasiana.com/arditasyalwa/5e7ba8d6097f36116506b8a2/p embelajaran-daring-efektif. (Diakses 14 juni 2020).

M.Ramli, "Hakikat pendidik dan peserta didik", Tarbiyah Islamiyah vol. 5, no. 1 (2015). Diakses pada tanggal 16 juli 2020.

Puti Hana Febriana, “Analisis penggunaan gadget terhadap kemampuan Interaksi sosial pada anak usia dini", jurnal obsesi: jurnal pendidikan anak usiadini, Vol 1. 2007. Diakses pada tanggal 16 april 2020

Oik yusuf, pengguna internet Indonesia nomor enam dunia, https://kominfo.go.id, sorotan_mediahasil web Indonesia RaksasaTeknologi Digital AsiakementrianKomunikasi dan Informatika. (diakses 18 agustus 2019). 